\title{
THE EFFECT OF PHOTODYNAMIC THERAPY ON THE VIABILITY OF STREPTOCOCCUS MUTANS ISOLATED FROM ORAL CAVITY
}

\author{
Ji-Sook Jung', Ho-Won Park', Ju-Hyun Lee', Hyun-Woo Seo', Si-Young Lee² \\ ${ }^{I}$ Department of Pediatric Dentistry, ${ }^{2}$ Department of Microbiology and Immunology, Oral Science Research Center, \\ College of Dentistry, Gangneung-Wonju National University
}

\section{Abstract}

Photodynamic therapy (PDT) is a technique that involves the activation of photosensitizer by light in the presence of tissue oxygen, resulting in the production of reactive radicals capable of inducing cell death. The aim of this study was to evaluate the effect of PDT on Streptococcus mutans in planktonic conditions, previously treated with different photosensitive concentrations of erythrosine, using halogen and LED curing unit as a light source. And we compared the effects of PDT on six strains of $S$. mutans isolated from oral cavity and reference strain.

As a result, S. mutans was susceptible to the combination of hand held photopolymerizer (HHP) and erythrosine. The higher concentration of erythrosine in the presence of light irradiation induced greater effects in reduction of viability of $S$. mutans. Isolated $S$. mutans showed a significant reduction in bacterial counts of the groups submitted to PDT compared to the control groups. And they appeared to be similar or slightly lower antimicrobial effect compared with reference strain. However, the difference was not significant $(p<0.05)$.

In conclusion, PDT using erythrosine as a photosensitizing agent and HHP as a light source could be an efficient option for diseases caused by $S$. mutans.

Key words : Photodynamic therapy, Erythrosine, Halogen, LED, Streptococcus mutans

\section{Introduction}

Many of oral diseases are caused by microorganisms. Dental caries is among the most significant human chronic contagious diseases ${ }^{1-3)}$. The Gram positive bacteria Streptococcus mutans is a substantial part of the dental plaque microbiota and its importance in the dental caries etiology is unquestionable ${ }^{4)}$. Mechanical removal of the biofilm, fluoride therapy, and adjunctive use of antibiotics have been conventional methods to control bacterial proliferation in the mouth environments ${ }^{5.6)}$. But in practice, antibiotics are rarely used due to problems such as production of drug - resis- tant organisms and disruption of the normal microflora. As a result, there is a pronounced interest in the development of alternative antimicrobial concepts ${ }^{7-9)}$.

Photodynamic therapy (PDT) could be an alternative to conventional therapeutic methods. PDT, also known as photoradiation therapy, phototherapy, or photochemotherapy, involves the use of a photoactive dye (photosensitizer) that is activated by exposure to light of a specific wavelength in the presence of oxygen ${ }^{10)}$. The transfer of energy from the activated photosensitizer to available oxygen results in the formation of toxic oxygen species, such as singlet oxygen and free radicals. These very reactive chemical species can damage proteins,

\section{교신저자 : 이 주 현}

강원도 강릉시 죽헌길 7 / 강릉원주대학교 치과대학 소아치과학교실 / 033-640-2452 / ljh55@gwnu.ac.kr 원고접수일: 2012년 02월 07일 / 원고최종수정일: 2012년 07월 28일 / 원고채택일: 2012년 07월 31일

* 본 연구는 강릉원주대학교 2011년 기성회계 학술연구조성비 지원으로 이루어졌음. 
lipids, nucleic acids, and other cellular components ${ }^{10}$.

Among the various photosensitive agents used in PDT, there are merocyanine derivatives, phtalocyanines, hematoporphyrin and xanthenes dyes ${ }^{11}$. Erythrosine belongs to a class of cyclic compounds called xanthenes, which absorb light in the visible region, and the ability of erythrosine to initiate photochemical reactions is well documented ${ }^{12,13)}$. Erythrosine has an advantage over other photosensitizers, as it already targets dental plaque and has full approval for use in the mouth ${ }^{14}$.

Historically, large complex lasers which need certain technical support were required for PDT. In clinical settings, these lasers have been replaced by reliable, easy to - use light sources which no longer require complex technologies and expensive maintenance. The hand held photopolymerizer (HHP) used in dentistry for the light curing of restorative materials has been suggested as an alternative to the use of lasers because of their low cost and simplicity ${ }^{14,15)}$.

Previous studies have shown that PDT using erythrosine is capable of killing oral bacteria ${ }^{15-18}$. Recently, Park et $\mathrm{al}^{15)}$ proved that PDT effect of erythrosine as a photosensitizer and dental halogen curing unit as a light source to the planktonic condition of $S$. mutans. And they compared the susceptibility of $S$. mutans in different light irradiation time and distance.

In the present study, we evaluated the PDT effect on S. mutans, previously treated with different photosensitive concentrations of erythrosine, using two types of HHP as a light source. The goal of our study was to compare the viability of $S$. mutans according to concentration of photosensitizer. Furthermore, we compared the effects of PDT on six strains of $S$. mutans isolated from oral cavity and reference strain.

\section{Materials and methods}

\section{Bacterial strains and culture conditions}

Seven S. mutans strains, including one reference strain (ATCC 25175) and six clinical strains isolated from oral cavity were used in this study. The isolated strains were obtained from the Laboratory of Microbiology and Immunology, School of Dentistry of Gangneung - Wonju National University.

The bacteria were incubated in brain heart infusion broth (Becton, Dickinson and Company, Sparks, Maryland, USA) at $37^{\circ} \mathrm{C}$ for 18 hours under aerobic con- dition supplemented with $5 \% \mathrm{CO}_{2}$. The turbidity of bacterial suspensions was measured by spectrophotometer (Smart Plus 2700, Young - Woo Inst. Seoul, Korea). A standard curve relating the culture turbidity and bacterial cell numbers was established and utilized. The bacteria was diluted to $10^{7}$ colony - forming units $(\mathrm{CFU}) / \mathrm{mL}$ with phosphate buffered saline (PBS).

\section{Photosensitizer}

Erythrosine (Sigma-Aldrich, St. Louis, MO, USA) was used as photosensitizer. A stock solution of $2 \mathrm{mM}$ erythrosine was prepared in PBS. This solution was filter sterilized and stored at $-20^{\circ} \mathrm{C}$ in the dark.

In order to evaluate the characteristic absorption spectra for erythrosine solution, it was examined using a spectrophotometer (Optizen 3220 UV, Mecasys, Daejeon, Korea). Fig. 1 shows the characteristic absorption spectra for an erythrosine solution. It is worth emphasizing that this xanthene derivate presents an $\mathrm{ab}^{-}$ sorption band in the range of $460-550 \mathrm{~nm}$, which is similar to the emission spectra of conventional HHP (400 - $500 \mathrm{~nm}$ ), suggesting that it can be used to photoactivate the dye. The erythrosine absorption spectra, obtained in the presence of $5 \times 10^{5} \mathrm{CFU} / \mathrm{mL}$ of $\mathrm{S}$. $\mathrm{mu}^{-}$ tans, does not show any alteration (data not shown).

\section{Light source}

The light sources used in this study were conventional halogen curing unit (XL 3000, 3M ESPE, St. Paul, MN

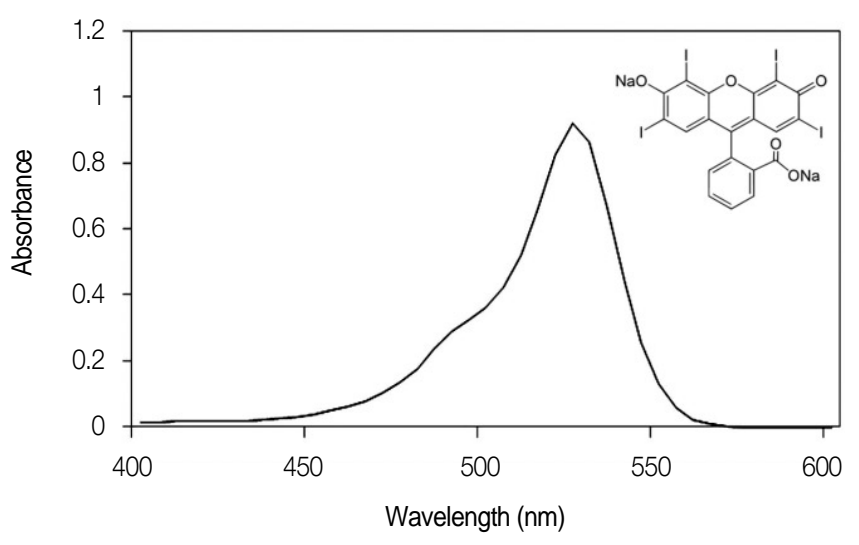

Fig. 1. Absorption spectra of erythrosine in PBS. Cuvette with bacterial suspension was used as reference. The erythrosine presents an absorption band in the range of $460-550 \mathrm{~nm}$, which is similar with the emission spectra of conventional HHP (400 - $500 \mathrm{~nm})$. Inset : Erythrosine structure. 
USA) and light - emitting diodes (LED) curing unit (Bluephase, Ivoclar Vivadent, Liechtenstein, Austria). The light beam of halogen curing unit irradiated diameter of $8 \mathrm{~mm}$ and that of LED curing unit was $10 \mathrm{~mm}$. The power output of the halogen light was $600 \mathrm{~mW} /$ $\mathrm{cm}^{2}$ and that of LED light was $900 \mathrm{~mW} / \mathrm{cm}^{2}$, checked by radiometer (Light intensity meter, Dentamerica, San Joes, California, USA). The halogen unit produces light spectrum of $370-530 \mathrm{~nm}$ with maximum at $470 \mathrm{~nm}$, and that of LED unit is $380-515 \mathrm{~nm}$ with maximum at $480 \mathrm{~nm}$ according to the manufacturer.

\section{Photodynamic therapy}

1) PDT according to the concentration of erythrosine

An aliquot (17.5 $\mu \mathrm{L}$ ) of $S$. mutans suspension (reference strain, final concentration of $5 \times 10^{5} \mathrm{CFU} / \mathrm{mL}$ ) was added to each well of sterile flat - bottomed 96 well plate. Next, the erythrosine $(3.5 \mu \mathrm{L})$ was added for group 3 and group 4. PBS was added for final volume of $350 \mu \mathrm{L}$.

Samples were divided into four test groups.

- Group 1 (P- $\left.\mathrm{L}^{-}\right)$- Neither irradiation nor photosensitizer treatment

- Group $2(\mathrm{P}-\mathrm{L}+)$ - Irradiation only

- Group $3\left(\mathrm{P}+\mathrm{L}^{-}\right)$- Treatment with photosensitizer only, no irradiation (Subgroups were divided by concentration of erythrosine)

- Group $4(\mathrm{P}+\mathrm{L}+)$ - Irradiation using photosensitizer (Subgroups were divided by concentration of erythrosine)

Each group was duplicated. The distance between the light tip and sample was $1 \mathrm{~cm}$. The light irradiation time was 30 seconds and it was performed immediately after addition of erythrosine. The final concentration of erythrosine of subgroups is as follows: $20,10,5,2.5,1.25$, $0.625 \mu \mathrm{M}$. Each experiment was performed with the halogen curing unit and the LED curing unit in the same way. After irradiation, each sample was diluted to 1/100 with PBS and $50 \mu \mathrm{L}$ of diluted suspension was spread on duplicate blood agar plates (Hanil - KOMED, Seongnam, Gyeonggi - do, Korea).

The plates were incubated for 72 hours at $37^{\circ} \mathrm{C}$ under aerobic condition supplemented with $5 \% \mathrm{CO}_{2}$. The number of CFU was then determined.

2) PDT on the isolated S. mutans strains

Bacterial suspensions of six clinical strains isolated from oral cavity, produced in the same way as reference strain, subjected to the following treatments: no light or photosensitizer ( $\left.\mathrm{P}^{-} \mathrm{L}^{-}\right)$, light alone without photosensitiz ${ }^{-}$ er $(\mathrm{P}-\mathrm{L}+)$, photosensitizer alone without light $\left(\mathrm{P}+\mathrm{L}^{-}\right)$, light with photosensitizer $(\mathrm{P}+\mathrm{L}+)$. At these experiments, erythrosine at $5 \mu \mathrm{M}$ concentration and halogen curing unit with 30 seconds irradiation time were used. After irradiation, each sample was diluted and incubated in the same way as reference strain. And the bacterial viability was determined by colony forming unit (CFU).

\section{3) Statistical analysis}

Statistical analysis was done by using the Software Package for Social Sciences (SPSS, version 12.0, SPSS Inc., USA). The arithmetic average and standard deviation were calculated in each group. Mann Whitney non parametric tests were utilized for assessing the data. The level of significance was $p<0.05$. One - way analysis of variance was used to analyze differences among subgroups and the Bonferroni method was performed for multiple comparison procedures.

\section{Results}

The reduction of CFU in each of the test groups is tabulated for each concentration of erythrosine. Mean and standard deviation values of the CFU obtained are shown in Table 1 and Table 2. Comparison between group 1, 2 and 3 reveals that treatment with light irradiation in the absence of photosensitizer (group 2) or photosensitizer in the absence of light irradiation (group 3) does not have antibacterial effect. A decrease in the number of colony counts was only verified when they were exposed to both the light and the photosensitizer at the same time (group 4).

When using halogen curing unit, in concentrations of erythrosine above $2.5 \mu \mathrm{M}$, significant decreases in colony counts were observed $(p<0.05)$. In concentrations above $5 \mu \mathrm{M}$, the bactericidal rate went up above 90\% (Table $1)$. There was a significant decrease in colony counts at $2.5 \mu \mathrm{M}$ concentration $(p<0.05)$, but even then, about $63.6 \%$ of tested organisms survived. No statistically significant difference between 1.25 and $0.625 \mu \mathrm{M}$ of erythrosine.

When using a LED curing unit, in all tested concentrations of erythrosine, significant decreases in colony counts were observed $(p<0.05)$. In concentrations above $5 \mu \mathrm{M}$, the bactericidal rates went up to above $90 \%$ 
Table 1. Photodynamic activity using halogen curing unit

\begin{tabular}{|c|c|c|c|c|}
\hline Group & Concentraion of dye $(\mu \mathrm{M})$ & $\begin{array}{c}\text { Mean } \pm \mathrm{SD} \\
\left(5 \times 10^{5} \mathrm{CFU} / \text { well }\right)\end{array}$ & Killing rate $(\%)$ & $p$-value \\
\hline Group 1 (P-L-) & & $23.00 \pm 3.8$ & 0 & \\
\hline Group 2 (P-L+) & & $2.345 \pm 4.8$ & 0 & 0.773 \\
\hline \multirow{6}{*}{ Group 3 (P+L-) } & 20 & $20.83 \pm 1.3$ & 9.4 & 0.773 \\
\hline & 10 & $19.08 \pm 0.6$ & 17 & 0.149 \\
\hline & 5 & $20.30 \pm 3.6$ & 11.7 & 0.248 \\
\hline & 2.5 & $23.66 \pm 6.0$ & 0 & 0.655 \\
\hline & 1.25 & $19.18 \pm 0.6$ & 16.6 & 0.248 \\
\hline & 0.625 & $20.09 \pm 0.5$ & 12.6 & 0.386 \\
\hline \multirow{6}{*}{ Group $4(\mathrm{P}+\mathrm{L}+)$} & 20 & $0.02 \pm 0.0^{*, \mathrm{a}}$ & 99.9 & 0.018 \\
\hline & 10 & $0.02 \pm 0.0^{*, \mathrm{a}}$ & 99.9 & 0.018 \\
\hline & 5 & $2.01 \pm 0.8^{*, \mathrm{a}}$ & 91.4 & 0.021 \\
\hline & 2.5 & $14.63 \pm 1.9^{*, \mathrm{~b}}$ & 36.4 & 0.021 \\
\hline & 1.25 & $16.82 \pm 2.8^{b}$ & 26.9 & 0.083 \\
\hline & 0.625 & $17.64 \pm 1.9^{b}$ & 23.3 & 0.083 \\
\hline
\end{tabular}

One - way ANOVA, Mean \pm SD

* Comparing to group 1 , statistically significant with $p<0.05$

${ }^{a, b}$ Different letters indicate significant differences among group $4(p<0.05)$

Table 2. Photodynamic activity using LED curing unit

\begin{tabular}{|c|c|c|c|c|}
\hline Group & Concentraion of dye $(\mu \mathrm{M})$ & $\begin{array}{c}\text { Mean } \pm \text { SD } \\
\left(10^{4} \mathrm{CFU} / \text { well }\right)\end{array}$ & Killing rate (\%) & $p$-value \\
\hline Group 1 (P-L-) & & $28.98 \pm 0.40$ & 0 & \\
\hline Group $2(\mathrm{P}-\mathrm{L}+)$ & & $45.05 \pm 17.7$ & 0 & 0.559 \\
\hline \multirow{6}{*}{ Group 3 (P+L-) } & 20 & $28.77 \pm 8.1$ & 0.7 & 1.000 \\
\hline & 10 & $27.09 \pm 4.9$ & 6.5 & 1.000 \\
\hline & 5 & $27.16 \pm 3.6$ & 6.3 & 1.000 \\
\hline & 2.5 & $26.36 \pm 2.2$ & 9.1 & 0.080 \\
\hline & 1.25 & $30.98 \pm 7.5$ & 0 & 0.243 \\
\hline & 0.625 & $28.37 \pm 1.3$ & 2.1 & 0.243 \\
\hline \multirow{6}{*}{ Group $4(\mathrm{P}+\mathrm{L}+)$} & 20 & $0.46 \pm 0.6^{*, a}$ & 98.4 & 0.019 \\
\hline & 10 & $0.26 \pm 0.3^{*, a}$ & 99.1 & 0.019 \\
\hline & 5 & $1.37 \pm 1.2^{*, a}$ & 95.3 & 0.019 \\
\hline & 2.5 & $11.39 \pm 4.5^{*, \mathrm{~b}}$ & 60.7 & 0.019 \\
\hline & 1.25 & $13.42 \pm 1.8^{*, \mathrm{~b}}$ & 53.7 & 0.019 \\
\hline & 0.625 & $22.37 \pm 2.0^{*, \mathrm{c}}$ & 32.8 & 0.019 \\
\hline
\end{tabular}

One - way ANOVA, Mean \pm SD

* Comparing to group 1 , statistically significant with $p<0.05$

a,b,c Different letters indicate significant differences among group $4(p<0.05)$

(Table 2). There was a significant decrease in colony counts at $0.625 \mu \mathrm{M}(p<0.05)$, but even then, about $67.2 \%$ of tested organisms survived.

Fig. 2 shows a direct comparison of the efficacy of erythrosine concentration in the PDT of $S$. mutans. It shows percentage of bacteria killing based on colony counts of control group. In cut off level of $p<0.05$ of significance, using halogen curing unit at above $2.5 \mu \mathrm{M}$ and using LED curing unit at all tested concentrations showed significant decreases of colony counts.

Table 3 and Fig. 3 show the PDT effect on six strains of $S$. mutans isolated from oral cavity. A significant reduction in bacterial counts was observed for the groups submitted to PDT $(\mathrm{P}+\mathrm{L}+)$ when compared to the control groups ( $\left.\mathrm{P}-\mathrm{L}^{-}\right)$. Table 3 shows the $\mathrm{CFU} /$ well reduc ${ }^{-}$ tion and killing rate observed from the $\mathrm{P}+\mathrm{L}+$ groups compared to the control groups. Whereas the killing rate of reference $S$. mutans went up to above $90 \%$ at $5 \mu \mathrm{M}$, the isolated $S$. mutans appeared to be similar or slightly lower killing rate than the reference strain (ranging from $69.7 \%$ to $92.45 \%)$. However, the difference was not significant $(p<0.05)$. 


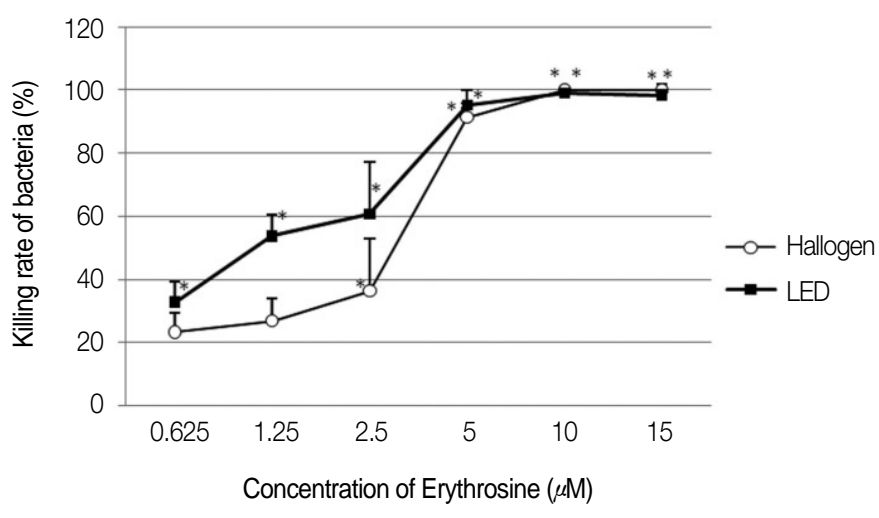

Fig. 2. Mean percentage of bacteria killing of each subgroup by concentration of erythrosine in group $4(\mathrm{P}+\mathrm{L}+)$. Using halogen curing unit at above $2.5 \mu \mathrm{M}$ and using LED curing unit at all tested concentrations showed significant decrease of colony counts. Error bars represent standard deviations. Irradiated with halogen (open circle); irradiated with LED (filled square).

(One - way ANOVA : $p<0.05$ )

\section{Discussion}

Photodynamic action has been used to kill oral microorganisms since the beginning of the 1990s, when studies demonstrated that some photosensitizers show affinity for bacterial walls and can be photoactivated to cause the desired damage ${ }^{19-21)}$. Excited photosensitizer molecules can transfer energy to nearby molecules, resulting in the formation of reactive molecules as singlet oxygen, superoxide, and other free radicals, capable of causing damage and even death of cells and bacteria ${ }^{22-25}$.

The successful application of PDT in inactivating microorganisms mainly depends on photosensitizer and light source. Dental practitioners currently use erythrosine to stain and visualize dental plaque in the form of disclosing solution or tablets. And noncoherent blue light sources such as halogen lamp and LED are commonly used in dentistry for photopolymerization of tooth - $\mathrm{col}^{-}$ ored restorative materials. By applying the same light sources and photosensitizer, we can now demonstrate a phototoxic effect on the Gram - positive bacteria $S$. $m u$ tans associated with dental caries.

Historically, lasers are the most common light sources used to activate the photosensitizers. However, recently, reliable and easy - to - use light sources which no longer require complex technologies and expensive maintenance have replaced conventional lasers. In this study, light sources of low cost, simple technology without UV - A or

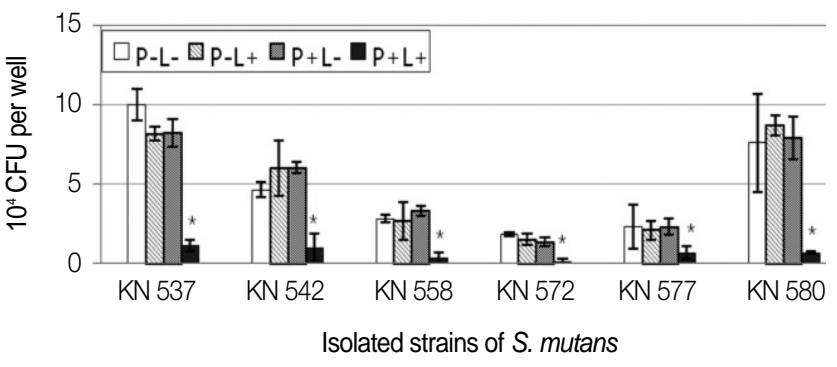

Fig. 3. Mean CFU / well of obtained for six strains of $S$. mutans isolated from oral cavity under different experimental conditions - presence / absence of erythrosine, or light source. A significant reduction in bacterial counts was observed for the groups submitted to PDT $(\mathrm{P}+\mathrm{L}+)$. Error bars present standard deviations.

$($ One - way ANOVA : $p<0.05)$

Table 3. Mean CFU/well and killing rate of isolated S. mutans strains

\begin{tabular}{crrrrc}
\hline $\begin{array}{c}\text { Strains of S. mutans } \\
(\mathrm{n}=4)\end{array}$ & \multicolumn{3}{c}{$5 \times 10^{5} \mathrm{CFU} /$ well } & \multicolumn{3}{r}{ Killing rate } \\
\hline KN 537 & 10.01 & 8.19 & 8.24 & $1.16^{*}$ & 88.48 \\
KN 542 & 4.66 & 6.02 & 6.04 & $0.95^{*}$ & 76.05 \\
KN 558 & 2.84 & 2.71 & 3.33 & $0.33^{*}$ & 88.27 \\
KN 572 & 1.86 & 1.54 & 1.35 & $0.14^{*}$ & 92.45 \\
KN 577 & 2.31 & 2.12 & 2.31 & $0.70^{*}$ & 69.70 \\
KN 580 & 7.61 & 8.70 & 7.95 & $0.69^{*}$ & 90.99 \\
\hline ATCC 25175 & 22.99 & 23.45 & 20.30 & $2.01^{*}$ & 91.40
\end{tabular}

One - way ANOVA, Mean \pm SD

* Comparing to control group (P-L-), statistically significant with $p<0.05$.

UV - B radiation, and photosenstive dye (erythrosine) which shows strong absorbance in the green region (maximum about $520 \mathrm{~nm}$, wide spectra) were used. Since it was observed that the dye has not altered its absorbancy spectra in the presence of the $S$. mutans, we might suggest that its molecular structure was not altered and there is no aggregation process which could reduce its efficiency in the reactive oxygen species (superoxide, hydroxyl radicals, hydrogen peroxide) liberation after irradiation with the HHP. Upon irradiation with light corresponding to an absorption maximum of the photosensitizer, cytotoxic reactive oxygen species are produced that can cause rapid oxidation of cellular constituents and cell death ${ }^{26)}$.

Previous study reported that PDT with erythrosine and dental halogen curing unit is available for killing $S$. mutans in planktonic state ${ }^{15}$. According to this study, PDT effect was more effective with increasing irradiation time and closer to the light source. Under irradiation for 
30 seconds at $1 \mathrm{~cm}$ distance, approximately 90\% of the bacteria showed decrease, which is an appropriate level to evaluate the effect of erythrosine concentration on PDT. Therefore, we used the light irradiation for $30 \mathrm{sec}^{-}$ onds at the distance of $1 \mathrm{~cm}$ in this present study. We have performed these experiments with variable concentrations of erythrosine (ranging from 0 to $20 \mu \mathrm{M}$ ) and two types of light sources (halogen and LED). Significant bactericidal effects were observed at concentrations of erythrosine above $2.5 \mu \mathrm{M}$ with halogen and all concentrations with LED. The reductions in viability of more than $90 \%$ with both light sources were observed using erythrosine concentration of $5 \mu \mathrm{M}$.

We noted that the general effect of toxicity with exposure to light increases with increasing concentration of photosensitizer. Preveious studies reported the similar results $^{27.28)}$. Goulart et $\mathrm{al}^{27)}$ verified that rose Bengal at $0.1 \mu \mathrm{M}$, associated with $0.65 \mathrm{~J} / \mathrm{cm}^{2}$ light irradiation, reduced the Aggregatibacter actinomycetemcomitans biofilm by approximately $45 \%$. This reduction was significantly dependent on concentration of rose bengal and dose irradiation. According to Jucaira et $\mathrm{al}^{28)}$, Photogem / toluidine blue $\mathrm{O}$ mediated PDT effect on the viability of S. mutans and Lactobacillus acidophilus in planktonic state was dependent on both photosensitizer concentration and light dose.

In PDT, the dye should not cause cell damage, that is, without light exposure; an ideal dye has no toxic effect on the cells, and the conditions used for the photoinactivation of any pathogen with PDT (light dose and dye concentration) should not affect the neighboring human tissues either. Erythrosine in concentrations ranging from 9 to $15 \mathrm{mM}$ is used in dentistry procedures to visualize dental plaque ${ }^{29)}$. All concentrations of erythrosine used in the present study are much lower than the currently acceptable clinically used concentration. Also, there are protection and repair systems in the eukaryotes like superoxide dismutases enzymes present in the cytoplasm and mitochondria, as well as some catalases. In addition to that, the presence of metal - substituted poliene such as carotene and lycopene, and vitamins that are often absent in prokaryotes such as vitamin $\mathrm{E}$ and $\mathrm{C}$, would work as anti - free radical agents in the eukaryotes, providing a higher protection against reactive species generated by PDT $^{30,31}$.

The efficacy of PDT with erythrosine in S. mutans has been previously studied ${ }^{16.17)}$. Wood et $\mathrm{al}^{16)}$ compared the use of three different photosensitizing agents: erythro- sine, Photofrin, and methylene blue at $22 \mu \mathrm{M}$ for each dye concentration to photosensitize the $S$. mutans biofilm, using $400 \mathrm{~W}$ tungsten lamp. Erythrosine was more effective than Photofrin or methylene blue, reducing S. mutans biofilm up to $48 \%$, compared with methylene blue (41\%) and Photofrin (just 0.04\%). Metcalf et $\mathrm{al}^{17)}$ has also verified the PDT effect on biofilm formed by S. mutans using $22 \mu \mathrm{M}$ of erythrosine and a light dose of $6.75 \mathrm{~J} / \mathrm{cm}^{2}$ : it induced $57 \%$ of biofilm cell reduction.

In this study, we demonstrated the antimicrobial efficacy of PDT using erythrosine and HHP against the seven $S$. mutans strains studied, including one reference strain (ATCC 25175) and six S. mutans strains previously isolated from the oral cavities of different individuals. We included these clinical strains of $S$. mutans to confirm that the effects of PDT would be more biologically relevant. To evaluate the effects of PDT on the isolated strains, we used erythrosine concentration of $5 \mu \mathrm{M}$, which showed bacterial reduction about $90 \%$ in the reference strain. A significant reduction in bacterial counts of the groups submitted to PDT in the isolated $S$. $\mathrm{mu}^{-}$ tans, when compared with the control groups, was observed. And the reduction rate in the isolated S. mutans appeared to be similar or slightly lower than the reference strain. Carolina et $\mathrm{al}^{32)}$ has verified the effect of photodynamic therapy with erythrosine using a LED on planktonic cultures of ten $S$. mutans strains, including nine clinical strains and one reference strain (ATCC 35688). The results showed that PDT with erythrosine exerted an antimicrobial effect on all $S$. mutans strains studied. They reported that no significant difference was observed between the isolated strains and the reference strain. The results agreed with our study. However, while they irradiated the light for 3 minutes, we acquired a similar antibacterial effect with reduced irradiation time (30 seconds).

Many works have demonstrated that bacteria of the oral cavity grown in planktonic media are sensitized by PDT. However, microorganisms that cause oral disease are organized in biofilm, which presents some different characteristics from those observed in planktonic growth, such as the presence of extracellular polymeric substances (EPS), as well as different cell wall composition, growth, metabolic activity, and gene expression ${ }^{33)}$. Because the bacteria grown in the biofilm may be more resistant to PDT, further study is required to evaluate the effect of PDT with erythrosine and HHP to $S$. $m u^{-}$ tans in vitro or vivo biofilm condition. Based in this 
study, it is possible to suggest that the condition of this experiment should be a good model in more extensive experiments using erythrosine and HHP.

\section{Conclusion}

We studied PDT effect of erythrosine as a photosensitizer and HHP (halogen curing unit and LED curing unit) as a light source on the planktonic condition of $S$. mutans. We concluded the followings.

1. S. mutans was susceptible to the combination of HHP (halogen curing unit and LED curing unit) and erythrosine in planktonic conditions.

2 . The higher concentration of erythrosine in the presence of light irradiation induced greater effects in reduction of viability of $S$. mutans. That is, the antibacterial effect of PDT was photosensitizer concentration dependent.

3. The activity of erythrosine or HHP (halogen curing unit and LED curing unit) alone was not able to reduce the number of $S$. mutans.

4. Isolated $S$. mutans showed a significant reduction in bacterial counts of the groups submitted to PDT when compared to the control groups. And they appeared to be similar or slightly lower antimicrobial effect compared with reference strain. However, the difference was not significant $(p<0.05)$.

The results of this study proved the PDT using erythrosine as a photosensitizing agent and HHP (halogen curing unit and LED curing unit) as a light source routinely used in dental clinic could be an efficient option for $S$. mutans. Based on these results, further study is required to evaluate the effect of PDT with erythrosine and HHP to $S$. mutans in biofilm conditions, in vitro and in vivo.

\section{References}

1. Krasse B : Caries risk: a practical guide for an assessment and control. chicago: Quintessence Publishing, 1985.

2. Smith DJ : Dental caries vaccines: prospects and concerns. Crit Rev Oral Biol Med, 13:335-349, 2002.

3. Marsh PD : Are dental diseases examples of ecological catastrophes? Microbiology, 149:279-294, 2003.

4. Mikkelsen L, Jensen SB, Jakobsen J : Microbial studies on plaque from carious and caries-free proxi- mal tooth surfaces in a population with high caries experience. Caries Res, 15:428-435, 1981.

5. Cox SD, Lassiter MO, Miller BS, Doyle RJ : A new mechanism of action of fluoride on streptococci. Biochim Biophys Acta, 1428:415-423, 1999.

6. Hirasawa M, Takada K : Susceptibility of Streptococcus mutans and Streptococcus sobrinus to cell wall inhibitors and development of a novel selective medium for $S$. sobrinus. Caries Res, 36:155160, 2002.

7. Walker $\mathrm{CB}$ : The acquisition of antibiotic resistance in the periodontal microflora. Periodontol, 10:79-88, 1996.

8. Manch-Citron JN, Lopez GH, Dey A, et al. : PCR monitoring for tetracycline resistance genes in subgingival plaque following site-specific periodontal therapy. A preliminary report. $J$ Clin Periodontol, 27:437-446, 2000.

9. Feres M, Haffajee AD, Allard K, et al. : Antibiotic resistance of subgingival species during and after antibiotic therapy. J Clin Periodontol, 29:724-735, 2002

10. Konopka K, Goslinski T : Photodynamic therapy in dentistry. J Dent Res, 86:694-707, 2007.

11. Tran J, Olmsted III J : Intramolecular triplet-triplet energy transfer from xanthene dyes to an anthyrl substituent. J Photochem Photobiol A Chem, 71:4549, 1993

12. Conlon KA, Berrios M : Light-induced proteolysis of myosin heavy chain by Rose Bengal-conjugated antibody complexes. $J$ Photochem Photobiol B, 65:2228, 2001.

13. Sharman WM, Allen CM, van Lier JE : Photodynamic therapeutics: basic principles and clinical applications. Drug Discov Today, 4:507-517, 1999.

14. Wood S, Metcalf D, Devine D, Robinson C : Erythrosine is a potential photosensitizer for the photodynamic therapy of oral plaque biofilms. $J$ Antimicrob Chemother, 57:680-684, 2006.

15. Park MS : Susceptibility of Streptococcus mutans to photodynamic therapy with erythrosine and dental halogen curing unit. Unpublished master's thesis, Gangneung-Wonju National University, 1-17, 2011.

16. Zanin IC, Goncalves RB, Junior AB, et al. : Susceptibility of Streptococcus mutans biofilms to photodynamic therapy: an in vitro study. $J$ Antimicrob Chemother, 56:324-330, 2005. 
17. Metcalf D, Robinson C, Devine D, Wood S : Enhancement of erythrosine-mediated photodynamic therapy of Streptococcus mutans biofilms by light fractionation. J Antimicrob Chemother, 58:190-192, 2006.

18. Goulart TG, Souza SL, Tedesco AC : Ciancaglini P : Comparative study of methylene blue and erythrosine dyes employed is Photodynamic therapy for inactivation of planktonic and biofilm-cultivated Aggregatibacter actinomycetemcomitans. Photomed Laser Surg, 28:85-90, 2010.

19. Wilson M : Photolysis of oral bacteria and its potential use in the treatment of caries and periodontal disease. J Appl Bacteriol, 75:299-306, 1993.

20. Wilson M, Dobson J, Sarkar S : Sensitization of periodontopathogenic bacteria to killing by light from a low-power laser. Oral Microbiol Immunol, 8:182187, 1993.

21. Wilson M, Pratten J, Pearson GJ : Bacteria in supragingival plaque samples can be killed by lowpower laser light in the presence of a photosensitizer. J Appl Bacteriol, 78:569-574, 1995.

22. Sibata CH, Colussi VC, Oleinick NL, Kinsella TJ : Photodynamic therapy: a new concept in medical treatment. Braz J Med Biol Res, 33:869-880, 2000.

23. Wilson $M$ : Photodynamic antimicrobial chemotherapy (PACT). J Antimicrob Chemother, 42:13-28, 1998.

24. Zvi M, Yeshayau N : New trends in photobiology bactericidal effects of photoactivated porphyrins - An alternative approach to antimicrobial drugs. $J$ Photochem Photobiol B, 5:281-293, 1990.
25. Tamietti BF, Machado AH, Maftoum-Costa M, et al. : Analysis of mitochondrial activity related to cell death after PDT with AlPCS4. Photomed Laser Surg, 25:175-179, 2007.

26. Dougherty TJ, Gomer CJ, Henderson BW, et al. : Photodynamic therapy. $J$ Natl Cancer Inst, 90:889905, 1998.

27. Goulart RC, Bolean M, Paulino TP, et al. : Photodynamic therapy in planktonic and biofilm cultures of Aggregatibacter actinomycetemcomitans. Photomed Laser Surg, 28:53-60, 2010.

28. Giusti JS, Santos-Pinto L, Pizzolito AC, et al. : Antimicrobial photodynamic action on dentin using a light-emitting diode light source. Photomed Laser Surg, 26:281-287, 2008.

29. Marsh PD, Bevis RA, Newman HN : Antibacterial activity of some plaque-disclosing agents and dyes. Caries Res, 23:348-350, 1989.

30. Slupphaug G, Kavli B, Krokan HE : The interacting pathways for prevention and repair of oxidative DNA damage. Mutat Res, 531:231-251, 2003.

31. Mortensen A, Skibsted LH, Truscott TG : The interaction of dietary carotenoids with radical species. Arch Biochem Biophys, 385:13-19, 2001.

32. Costa AC, Chibebe Junior J, Pereira CA, et al. : Susceptibility of planktonic cultures of Streptococcus mutans to photodynamic therapy with a light-emitting diode. Braz Oral Res, 24:413-418, 2010.

33. Costerton JW, Stewart PS, Greenberg EP : Bacterial biofilms: a common cause of persistent infections. Science, 284:1318-1322, 1999. 


\section{광역동 치료가 구강 내에서 분리한 수종의 Streptococcus mutans의 생존력에 미치는 영향

\author{
정지숙 ${ }^{1} \cdot$ 박호원 $^{1} \cdot$ 이주현 $^{1} \cdot$ 서현우 $^{1} \cdot$ 이시영 ${ }^{2}$
}

강릉원주대학교 치과대학 ${ }^{1}$ 소아치과학교실, ${ }^{2}$ 미생물학 및 면역학 교실 및 구강과학연구소

광역동 치료는 광감각제가 빛에 의해 활성화되면서 발생하는 화학 반응을 이용한 것으로, 치료 원리는 광화학 반응으로 자 유 라디칼 및 반응성 산소가 생성되고 이 산물들에 의한 세포 독성으로 항균 효과를 가지게 되는 것이다.

이 연구의 목적은 치과 임상에서 널리 사용되는 광원(할로겐, LED)과 광감각제(erythrosine)를 이용하여, 치아 우식증과 연관된 세균인 Streptococcus mutans에 대한 광역동 치료의 항균 효과를 알아보고, 광감각제의 농도에 따른 광역동 치료의 효과를 평가하기 위함이다. 또한 임상 분리 균주와 표준 균주에 대한 광역동 치료의 효과를 비교해 보았다.

연구 결과, 표준 및 임상 분리 균주 모두 광감각제 처리 후 광조사를 시행한 군에서만 대조군에 비해 S. mutans의 유의한 감소가 나타났다. 또한 광조사를 시행한 군에서 첨가한 광감각제의 농도가 높을수록 S. mutans의 감소가 증가하는 것으로 나타났다. 표준 균주와 비교 시 임상 분리 균주에서는 표준 균주와 비슷하거나 약간 낮은 S. mutans의 감소가 나타났고, 이 는 통계적으로 유의한 차이는 없었다 $(p<0.05)$.

이상의 결과들로 보아 광감각제로 에리스로신의 사용과 광원으로 치과용 광중합기를 사용한 광역동 치료는 S. mutanS 연 관 질병에 대한 효과적인 치료 방법이 될 수 있을 것으로 사료된다.

Key words : 광역동 치료, 에리스로신, 할로겐, LED, Streptococcus mutans 